http://dx.doi.org/10.15762/ZH.2015.30

\title{
BIBLIOGRAFIA PUBLIKACJI JERZEGO DYGDAŁY ZA LATA 1972-2014
}

Opracowali: Tomasz Krzemiński i Tomasz Łaszkiewicz

Skróty tytułów czasopism i wydawnictw seryjnych użyte w tekście:

Acta Pol. Hist. Acta Univ. N. Copern., Hist. Czas. Prawno-Hist. Czasy Nowoż. Kom. Maz.-Warm. Kwart. Hist. Kwart. Hist. Kult. Mat. Misc. Hist.-Arch. Pol. słow. biogr. Przegl. Reg. Rocz. Gd. Rocz. Grudz. Rocz. Tor. Słow. biogr. Pom. Nadwiśl. Stud. Marit. Stud. Pelpl. Stud. Źródłozn. Tor. słow. biogr. Wiek Oświec. Zap. Hist. Ziem. Kuj.
- Acta Poloniae Historica

- Acta Universitatis Nicolai Copernici, Historia

- Czasopismo Prawno-Historyczne

- Czasy Nowożytne

- Komunikaty Mazursko-Warmińskie

- Kwartalnik Historyczny

- Kwartalnik Historii Kultury Materialnej

- Miscellanea Historico-Archivistica

- Polski słownik biograficzny

- Przegląd Regionalny

- Rocznik Gdański

- Rocznik Grudziądzki

- Rocznik Toruński

- Słownik biograficzny Pomorza Nadwiślańskiego

- Studia Maritima

- Studia Pelplińskie

- Studia Źródłoznawcze

- Toruński słownik biograficzny

- Wiek Oświecenia

- Zapiski Historyczne

- Ziemia Kujawska

1972

1. Sprawozdanie z działalności Toruńskiego Oddziału Polskiego Towarzystwa Historycznego w 1971 r. Zap. Hist. T. 37 z. 2 s. 145-147.

2. Źródła do dziejów pierwszego rozbioru Polski w Archiwum Toruńskim. Zap. Hist. T. 37 z. 4 s. $133-149$.

3. Korespondencja rezydentów miasta Torunia na dworze królewskim w XVIII wieku w Archiwum Toruńskim. Acta Univ. N. Copern., Hist. nr 8 s. 85-107. 
4. Prusy Królewskie a konfederacja barska w Wielkopolsce 1768-1770. Zap. Hist. T. 38 z. 2 s. $109-120$.

[W związku z pracą: Szczygielski Wacław: Konfederacja barska w Wielkopolsce 1768-1770. Warszawa 1970]

5. Sprawozdanie z działalności Toruńskiego Oddziału Polskiego Towarzystwa Historycznego w 1972 r. Zap. Hist. T. 38 z. 2 s. 147-148.

6. Toruńska sesja naukowa z okazji 200 rocznicy pierwszego rozbioru Polski i aneksji przez Prusy Pomorza Gdańskiego. Zap. Hist. T. 38 z. 2 s. 148-150.

1976

7. Jeszcze o Prusach Królewskich i konfederacji barskiej w Wielkopolsce. Zap. Hist. T. 41 z. 1 s. $149-152$.

[W związku z repliką: Szczygielski Wacław: Toruń i Prusy Królewskie a konfederacja barska w Wielkopolsce. Zap. Hist. T. 41: 1976 z. 1 s. 129-148]

8. Próby wykorzystania mennicy toruńskiej przez dwór i władze Rzeczypospolitej w drugiej połowie XVIII wieku. Rocz. Tor. T. 11 s. 181-198.

9. Scenariusz wystawy // In: Dorobek stulecia Towarzystwa Naukowego w Toruniu. Katalog wystawy jubileuszowej / red. Tadeusz Zakrzewski. - Toruń: Tow. Nauk. w Toruniu. - s. 49-75.

10. Stulecie Towarzystwa Naukowego w Toruniu. Kwart. Hist. R. 83 nr 3 s. 738-739.

11. Wielkie miasta Prus Królewskich wobec reformy menniczej z lat 1765-1766. Zap. Hist. T. 41 z. 3 s. $105-123$.

\section{7}

12. Nałęcz Michał h. Nałęcz (1691-1761), burmistrz Torunia. // In: Pol. słow. biogr. T. 22 - Wrocław. - s. 493.

13. O genealogiach patrycjatu toruńskiego XVI-XVIII wieku. Zap. Hist. T. 42 z. 3 s. 85$-106$.

[Wspólnie ze Stanisławem Salmonowiczem; w związku z pracą: Marian Gumowski: Herbarz patrycjatu toruńskiego. Toruń 1970]

14. Opozycja Prus Królewskich wobec cła generalnego w latach 1764-1766. Zap. Hist. T. 42 z. 2 s. $25-44$.

15. Polityka Torunia wobec władz Rzeczypospolitej w latach 1764-1772. - Warszawa: PWN. - 211, [1] s.

16. Sprawozdanie z działalności Oddziału Polskiego Towarzystwa Historycznego w Toruniu w 1975 r. Zap. Hist. T. 42 z. 1 s. 171-173.

17. Toruń wobec unifikacji miar i wag Rzeczypospolitej w latach 1764-1766. Acta Univ. N. Copern., Hist. nr 11 s. 99-111.

18. Udział Gotfryda Lengnicha w toruńskiej konferencji dysydenckiej w 1767 roku. (Z problematyki stosunku Gdańska do kwestii różnowierczej w XVIII wieku). Zap. Hist. T. 42 z. 4 s. 9-30. 
1978

19. Oloff Efraim (1715-1766), rajca toruński. // In: Pol. słow. biogr. T. 23 - Wrocław. s. $826-827$.

20. Toruńskie czasopismo „Thornische Wöchentliche Nachrichten und Anzeigen”. (Problemy redakcji, zasięgu oddziaływania i profilu politycznego). Zap. Hist. T. 43 z. s. 67$-87$.

21. Rec. - Błażejewicz Olena: Samuel Bogumił Linde: bibliotekarz i bibliograf. Wrocław, 1975. - Zap. Hist. T. 43 z. 1 s. 142-145.

1979

22. Uwagi o magnaterii Prus Królewskich w XVIII stuleciu. Zap. Hist. T. 44 z. 3 s. 57-91.

23. Rec. - Zienkowska Krystyna: Sławetni i urodzeni. Ruch polityczny mieszczaństwa w dobie Sejmu Czteroletniego. Warszawa, 1976. - Zap. Hist. T. 44 z. 2 s. 123-125.

1980

24. Na marginesie badań nad magnaterią epoki saskiej. Rocz. Gd. T. 40 z. 1 s. 187-198.

25. Synteza Pomorza Nadwiślańskiego. Kom. Maz.-Warm. R. 24 nr 2 s. 230-239.

[Wspólnie z Maksymilianem Grzegorzem i Wojciechem Wrzesińskim]

26. Rec. - Metcalf Michael F.: Russia, England and Swedish party politics 1762-1766. The interplay between great power diplomacy and domestic politics during Sweden's age of liberty. Stockholm, 1977. - Zap. Hist. T. 45 z. 3 s. 160-163.

1981

27. Kwestia dopuszczenia małych miast Prus Królewskich do sejmiku generalnego w latach 1764-1768. Zap. Hist. T. 46 z. 1 s. 47-75.

28. Piwnicki Jan Franciszek h. Lubicz (I. poł. XVIII w.), poseł na sejmy, podwojewodzi chełmiński. // In: Pol. słow. biogr. T. 26. Wrocław. - s. 602-603.

29. Piwnicki Kazimierz h. Lubicz (zm. 1749), poseł na sejmy, miecznik inflancki, sędzia ziemski chełmiński. // In: Pol. słow. biogr. T. 26. Wrocław. - s. 603-604.

30. Piwnicki Konstanty Kazimierz (używał czasem wyłącznie imienia Kazimierz) h. Lubicz (2. poł. XVII w.), poseł na sejmy, podwojewodzi chełmiński. // In: Pol. słow. biogr. T. 26. Wrocław. - s. 604-605.

31. Piwnicki Walerian Józef h. Lubicz (1720-przed 1799), miecznik ziem pruskich, komisarz Komisji Skarbu Koronnego. // In: Pol. słow. biogr. T. 26. Wrocław. - s. 607-609.

32. Pląskowski Józef h. Oksza (zm. 1773), starosta brodnicki. // In: Pol. słow. biogr. T. 26. Wrocław. - s. 704-705.

33. Rec. - Łukowski George Tadeusz: The Szlachta and the Confederacy of Radom 1764-1767/68. A study of the Polish Nobility. Romae, 1977. - Kwart. Hist. R. 88 nr 3 s. $849-854$. 
34. Aktywność polityczna szlachty Prus Królewskich na przełomie czasów saskich i stanisławowskich. Próba kwantyfikacji. Zap. Hist. T. 47 z. 4 s. 181-200.

1983

35. Działalność Andrzeja Zamojskiego na sejmiku generalnym Prus Królewskich w Grudziądzu w październiku/listopadzie 1764 roku. Rocz. Grudz. T. 8 s. 47-64.

36. Konflikty społeczno-ustrojowe w Toruniu w latach 1716-1718. Mediacja kanclerza wielkiego koronnego Jana Szembeka. Zap. Hist. T. 48 z. 3 s. 71-104.

37. Rec. - Ciara Stefan: Kariera rodu Weiherów 1560-1657. Warszawa, 1980. - Zap. Hist. T. 48 z. 1/2 s. 281-285. [Wspólnie z Witoldem Szczuczko]

38. Rec. - Achremczyk Stanisław: Reprezentacja stanowa Prus Królewskich w latach 1696-1772. Skład społeczny i działalność. Olsztyn, 1981. - Kwart. Hist. R. 90 nr 2 s. $420-424$.

\section{4}

39. Gdańska sesja naukowa „Wkład Pomorza Gdańskiego do rozwoju nauki i oświaty”. Zap. Hist. T. 49 z. 3, s. 178-180.

40. Prymas Polski, Ksiądz Kardynał Józef Glemp w 750-letnim Toruniu, w diecezji chełmińskiej. (Uwagi o dziejach wyznaniowych miasta i diecezji). Stud. Pelpl. T. 15 s. 265-272 .

[Wspólnie z Janem Kostrzakiem]

41. Toruński jubileusz prof. dr. Mariana Biskupa. Kwart. Hist. R. 91 nr 2 s. 393.

42. Życie polityczne Prus Królewskich u schyłku ich związku z Rzecząpospolitą w XVIII wieku. Tendencje unifikacyjne a partykularyzm. - Warszawa: PWN. - 261, [2] s., ilustr.

43. Rec. - Wybitni Pomorzanie XVIII wieku. Szkice biograficzne. Wrocław, 1983. - Zap. Hist. T. 49 z. 4 s. 161-163.

44. Rec. - Zasłużeni ludzie Pomorza Nadwiślańskiego XVII wieku. Szkice biograficzne. Wrocław, 1982. - Zap. Hist. T. 49 z. 4 s. 159-161.

1985

45. Bibliografia prac profesora Jerzego Wojtowicza od 1952 roku. Acta Univ. N. Copern., Hist. nr 20 s. 7-16.

46. Biskupi chełmińscy i kujawscy doby potrydenckiej i ich rola w życiu Prus Królewskich (1569-1772). Stud. Pelpl. T. 16 s. 27-47.

47. Gdańska sesja naukowa poświęcona Stanisławowi Leszczyńskiemu i 250-leciu oblężenia Gdańska w 1734 roku. Zap. Hist. T. 50 z. 1 s. 170-171.

48. Obraz Wielkiej Rewolucji Francuskiej w hamburskim czasopiśmie „Historisch - politisches Magazin” (z problematyki stosunku hamburskiego mieszczaństwa do rewolucyjnej Francji). Acta Univ. N. Copern., Hist. nr 20 s. 169-181. 
49. Potulicki Jan Jakub h. Grzymała (ok. 1652-1726), poseł na sejmy, wojewoda brzeski kujawski. // In: Pol. słow. biogr. T. 28. Wrocław. - s. 246-248.

50. Pöppelmann Karol August (ok. 1741-1805), kanonik warmiński. // In: Pol. słow. biogr. T. 28. Wrocław. - s. 327-328.

51. Praetorius (Prätorius) Nataniel (1722-1791), burmistrz toruński. // In: Pol. słow. biogr. T. 28. Wrocław. - s. 339-340.

52. Próba reformy sejmiku generalnego Prus Królewskich w 1734 roku. Czas. Prawno-Hist. T. 37 z. 2 s. $243-255$.

53. Prusy Królewskie w dobie konfederacji barskiej 1768-1772. (Problematyka polityczna). Cz. 1. Zap. Hist. T. 50 z. 1 s. 17-38.

54. Prusy Królewskie w dobie konfederacji barskiej 1768-1772. (Problematyka polityczna). Cz. 2. Zap. Hist. T. 50 z. 2 s. 27-55.

55. Pruszak Józef h. Leliwa (zm. 1774), kasztelan gdański. // In: Pol. słow. biogr. T. 28. Wrocław. - s. 595-596.

56. Pruszak Tomasz Tadeusz h. Leliwa (ok. 1724-1808), kasztelan gdański. // In: Pol. słow. biogr. T. 28. Wrocław. - s. 596-597.

57. Przebendowski Ignacy Franciszek h. własnego (ok. 1730-1791), wojewoda pomorski, starosta generalny małopolski, marszałek Rady Nieustającej. // In: Pol. słow. biogr. T. 28. Wrocław. - s. 644-647.

58. Przebendowski Jakub h. własnego (ur. przed 1724-1787), kasztelan elbląski. // In: Pol. słow. biogr. T. 28. Wrocław. - s. 648-649.

59. Przebendowski Jan h. własnego (ur. po 1676-1729), krajczy kor. // In: Pol. słow. biogr. T. 28. Wrocław. - s. 658-659.

60. Przebendowski Józef Antoni h. własnego (zm. 1775), chorąży pomorski. // In: Pol. słow. biogr. T. 28. Wrocław. - s. 659-661.

61. Przebendowski Piotr Jerzy (ok. 1674-1755), wojewoda malborski. // In: Pol. słow. biogr. T. 28. Wrocław. - s. 664-667. [Wspólnie ze Stanisławem Achremczykiem]

62. Red. - Acta Universitatis Nicolai Copernici. Nauki Humanistyczno-Społeczne / Uniw. M. Kopernika w Toruniu. Toruń Z. 158: Historia. Studia z historii nowożytnej ofiarowane profesorowi Jerzemu Wojtowiczowi. Nr 20. - 223, [3] s., tabl. 1.

[Wspólnie z Januszem Małłkiem]

63. Obóz saski w Prusach Królewskich i jego działalność w latach 1733-1736. Rocz. Gd. T. 46 z. 1 s. $139-168$.

64. Przezdziecki Aleksander h. Roch III (ok. 1665-1733/4), kasztelan inflancki. // In: Pol. słow. biogr. T. 29. Wrocław. - s. 45.

65. Przezdziecki Antoni Tadeusz h. Roch III (1718-1772), podkanclerzy W. Ks. Lit. // In: Pol. słow. biogr. T. 29. Wrocław. - s. 51-54.

66. Przyłubski Wacław h. Poraj (ok. 1727-1775?), sędzia ziemski brzeski kujawski, poseł na sejmy. // In: Pol. słow. biogr. T. 29. Wrocław. - s. 204. 
67. Raczyński Kazimierz h. Nałęcz (1739-1824), pisarz w. kor., następnie starosta generalny wielkopolski, marszałek nadworny kor. // In: Pol. słow. biogr. T. 29. Wrocław. - s. 644-653.

68. Raczyński Leon h. Nałęcz (ok. 1698-1755), generał wojsk kor., kasztelan santocki. // In: Pol. słow. biogr. T. 29. Wrocław. - s. 653-654.

69. Raczyński Michał Kazimierz h. Nałęcz (1650-1737), kasztelan gnieźnieński i kaliski, wojewoda kaliski i poznański. // In: Pol. słow. biogr. T. 29. Wrocław. - s. 656-658.

70. Radomicki Andrzej (Jędrzej) Aleksander h. Kotowicz (przed 1660-1726), wojewoda poznański. // In: Pol. słow. biogr. T. 29. Wrocław. - s. 721-723.

71. Radomicki Jan Antoni h. Kotowicz (1691?-1728), wojewoda inowrocławski, starosta generalny wielkopolski. // In: Pol. słow. biogr. T. 29. Wrocław. - s. 725.

72. Radomicki Maciej h. Kotowicz (ok. 1648-1728), wojewoda inowrocławski i starosta generalny wielkopolski, następnie wojewoda poznański. // In: Pol. słow. biogr. T. 29. Wrocław. - s. 725-728.

73. Radomicki Władysław h. Kotowicz (ok. 1668-1737), kasztelan, potem wojewoda poznański. // In: Pol. słow. biogr. T. 29. Wrocław. - s. 728-730.

74. Radowicki Świętosław h. Grzymała (ok. 1675-1734), chorąży chełmiński. // In: Pol. słow. biogr. T. 29. Wrocław. - s. 755-757.

75. Rec. - Müller Michael G.: Polen zwischen Preussen und Russland. Souveränitätskrise und Reformpolitik 1736-1752. Berlin [West], 1983. - Zap. Hist. T. 51 z. 2 s. 95-100.

76. Rec. - Panorama der Friderizianischen Zeit. Friedrich der Grosse und seine Epoche. Ein Handbuch / hrsg. v. J. Ziechmann. Bremen, 1985. - Kwart. Hist. R. 93 nr 3 s. 880$-883$.

77. Główne kierunki badań historycznych w pozauczelnianych placówkach Pomorza Wschodniego w latach 1945-1985 // In: Rozwój nauki na Pomorzu Wschodnim w latach 1945-1985. Materiały z konferencji naukowej / red. Marian Biskup. - Toruń: Tow. Nauk. w Toruniu. - s. 83-98.

78. Sejmiki powiatowe województwa pomorskiego w czasach saskich i stanisławowskich (1696-1772). Zap. Hist. T. 52 z. 4 s. 79-103.

79. Rec. - Müller Michael G.: Die Teilungen Polens 1772-1793-1795. München, 1984. - Zap. Hist. T. 52 z. 3 s. $185-188$.

1988

80. Gdańskie sympozjum „Szlachta na Pomorzu Nadwiślańskim”. Zap. Hist. T. 53 z. 1/2 s. 200-201.

81. Rexin Michał Ernest h. własnego (ok. 1696-1768), starosta malborski, generał lejtnant. // In: Pol. słow. biogr. T. 31. Wrocław. - s. 181-183.

82. Reyher Jerzy Adam (1725-1799), burmistrz toruński. // In: Pol. słow. biogr. T. 31. Wrocław. - s. 215-216. 
83. Rogaliński Antoni h. Łodzia (ok. 1690-1761), starosta obornicki, sędzia ziemski wschowski. // In: Pol. słow. biogr. T. 31. Wrocław. - s. 400-401.

84. Rogaliński Kasper h. Łodzia (ok. 1725-1788), wojewoda inflancki. // In: Pol. słow. biogr. T. 31. Wrocław. - s. 404-408.

85. Przebendowscy - osiemnastowieczni magnaci w Prusach Królewskich // In: Najstarsze dzieje Wejherowa (Materiały z sesji naukowej) / red. Regina Osowicka. - Wejherowo: Muzeum Piśmiennictwa i Muzyki Kaszubsko-Pomorskiej. Tow. Przyj. Ziemi Wejherowskiej. - s. 75-91.

86. Rec. - Studia Maritima Vol. 4 1985. - Acta Pol. Hist. T. 57 s. 257-260.

87. Rec. - Müller Michael G.: Die Teilungen Polens 1772-1793-1795. München, 1984. - Acta Pol. Hist. T. 58 s. 171-175.

1989

88. Ewolucja poglądów politycznych młodego Józefa Wybickiego - od „Familii” Czartoryskich do konfederacji barskiej. Rocz. Gd. T. 49 z. 1 s. 123-133.

89. Toruńska dyskusja nad książką S. Salmonowicza o dziejach Prus. Zap. Hist. T. 54 z. 4 s. $165-166$.

90. Rec. - Cegielski Tadeusz: Das Alte Reich und die erste Teilung Polens 1768-1774. Warszawa-Stuttgart, 1988. - Kwart. Hist. R. 96 nr 3/4 s. 230-233.

91. Rec. - In Europas Mitte. Deutschland und seine Nachbarn. Bonn, 1988. - Kwart. Hist. R. $96 \mathrm{nr}$ 3/4 s. 201-204.

92. Rec. - Zielińska Teresa: Walka „Familii” o reformę Rzeczypospolitej 1743-1752. Warszawa, 1983. - Wiek Oświec. T. 7 s. 187-193.

\section{0}

93. Nawra Kruszyńskich i Sczanieckich. Studium z dziejów szlachty i ziemiaństwa ziemi chełmińskiej Toruń: Tow. Nauk. w Toruniu. - 177 s., [2] s., ilustr., tabl. geneal. 2. [Wspólnie ze Szczepanem Wierzchosławskim]

94. Rec. - Cieślak Edmund: W obronie tronu króla Stanisława Leszczyńskiego. Gdańsk, 1986. - Zap. Hist. T. 55 z. 1 s. 168-170.

95. Rec. - Łojek Jerzy: Dzieje zdrajcy. Katowice, 1988. - Kwart. Hist. R. 97 nr 3/4 s. 227-230 .

1991

96. Król Stanisław Leszczyński w Toruniu w styczniu 1708 roku. Rocz. Tor. T. 20 s. 241-252 .

97. Bagniewski Antoni (ok. 1710-1794), sędzia ziemski chełmiński. // In: Słow. biogr. Pom. Nadwiśl. T. 1 A-F. Gdańsk. - s. 52-53.

98. Baier Andrzej Ignacy h. Leliwa (1712-1785), bp chełmiński. // In: Słow. biogr. Pom. Nadwiśl. T. 1 A-F. Gdańsk. - s. 54-55. 
99. Bieliński Michał h. Junosza (po 1683-1746), woj. chełmiński. // In: Słow. biogr. Pom. Nadwiśl. T. 1 A-F. Gdańsk. - s. 103-104.

100. Bniński Konstanty h. Łodzia (zm. 1810), kasztelan chełmiński. // In: Słow. biogr. Pom. Nadwiśl. T. 1 A-F. Gdańsk. - s. 124-125.

101. Bystram Wacław h. Tarnawa (1710-1792), podkomorzy pom. // In: Słow. biogr. Pom. Nadwiśl. T. 1 A-F. Gdańsk. - s. 188-189.

102. Cocchi (Cochi, Cocchy, Koki) Jan Baptysta (1701-1759), rajca i architekt toruński. // In: Słow. biogr. Pom. Nadwiśl. T. 1 A-F. Gdańsk. - s. 229-230.

103. Czapski Antoni h. Leliwa (ok. 1723-1792), podkomorzy chełmiński. // In: Słow. biogr. Pom. Nadwiśl. T. 1 A-F. Gdańsk. - s. 247-248.

104. Czapski Franciszek Stanisław Kostka h. Leliwa (1725-1802), woj. chełmiński. // In: Słow. biogr. Pom. Nadwiśl. T. 1 A-F. Gdańsk. - s. 249-250.

105. Czapski Jan Ansgary h. Leliwa (1699-1742), woj. chełmiński, podskarbi wielki koronny. // In: Słow. biogr. Pom. Nadwiśl. T. 1 A-F. Gdańsk. - s. 252-253.

106. Czapski Michał h. Leliwa (1725? -1796), woj. malborski. // In: Słow. biogr. Pom. Nadwiśl. T. 1 A-F. Gdańsk. - s. 256-257.

107. Czapski Paweł Tadeusz h. Leliwa (ok. 1721-po 1783), gen.-mjr wojsk pol., uczony amator. // In: Słow. biogr. Pom. Nadwiśl. T. 1 A-F. Gdańsk. - s. 257-258.

108. Czapski Walenty Aleksander h. Leliwa (1682-1751), bp kujawski. // In: Słow. biogr. Pom. Nadwiśl. T. 1 A-F. Gdańsk. - s. 260-261.

109. Czarnecki Franciszek Ignacy (1714-1766), rajca toruński. // In: Słow. biogr. Pom. Nadwiśl. T. 1 A-F. Gdańsk. - s. 270-271. [Wspólnie z Kazimierzem Maliszewskim]

110. Donepe Antoni (1606-1663), burmistrz toruński. // In: Słow. biogr. Pom. Nadwiśl. T. 1 A-F. Gdańsk. - s. 338.

111. Działyński Jakub h. Ogończyk (1708-1756), woj. malborski. // In: Słow. biogr. Pom. Nadwiśl. T. 1 A-F. Gdańsk. - s. 365.

112. Dziewanowski Juliusz h. Jastrzębiec (zm. 1772), kasztelan chełmiński. // In: Słow. biogr. Pom. Nadwiśl. T. 1 A-F. Gdańsk. - s. 377-378.

113. Fleming Jan Jerzy h. własnego (1699-1771), woj. pom. // In: Słow. biogr. Pom. Nadwiśl. T. 1 A-F. Gdańsk. - s. 425-426.

114. Pałac Dąmbskich w Toruniu. Głos Uczelni. Pismo UMK nr 2 s. 12.

115. Rutkowski Józef Leon z Rutkowic h. Pobóg (ok. 1714-1744), sędzia ziemski dobrzyński, poseł na sejmy. // In: Pol. słow. biogr. T. 33. Wrocław. - s. 233-234.

116. Rybiński Jacek Józef h. Radwan (1702-1782), opat oliwski. // In: Pol. słow. biogr. T. 33. Wrocław. - s. 322-325.

117. Skład elity duchowieństwa katolickiego Prus Królewskich w latach 1660-1772. (Przyczynek do roli Kościoła w integracji prowincji pruskiej z pozostałymi ziemiami Rzeczypospolitej). Zap. Hist. T. 57 z. 2/3 s. 43-71.

118. Toruński „Inwentarz aktów sejmikowych Prus Królewskich [1600-1764]” (problemy autorstwa, okoliczności powstania oraz dyskusji wokół tego źródła) // In: Historia 
i archiwistyka. Księga pamiątkowa ku czci profesora Andrzeja Tomczaka. Toruń-Warszawa. - s. 189-199.

119. Rec. - Szorc Alojzy: Dominium warmińskie 1243-1772. Przywilej i prawo chełmińskie na tle ustroju Warmii. Olsztyn, 1990. - Kwart. Hist. R. 99 nr 4 s. 137-139.

120. Red. - Historia i archiwistyka. Księga pamiątkowa ku czci profesora Andrzeja Tomczaka. Toruń-Warszawa: Uniw. M. Kopernika w Toruniu, Naczelna Dyr. Arch. Państwowych. -350 s., [1] s., tabl. 1. [Wspólnie z Bolesławem Woszczyńskim]

121. Biskupi chełmińscy dawnej Rzeczypospolitej (1466-1772). Przegl. Reg. z. 7 s. 29-36.

122. Dylematy austriackiej polityki wobec Rzeczypospolitej podczas bezkrólewia 1733 roku. Acta Univ. N. Copernici. Hist. nr 28 s. 103-124.

123. Konflikty między kupiectwem Gdańska i Torunia z lat 1720-1724 // In: Strefa bałtycka w XVI-XVIII wieku. Polityka, społeczeństwo, gospodarka. Ogólnopolska sesja naukowa zorg. z okazji 70-lecia urodzin prof. Edmunda Cieślaka. Gdańsk 7 grudnia 1992 r. / red. Jerzy Trzoska. Gdańsk: Marpress. - s. 197-206.

124. Polityka informacyjna prymasa Teodora Potockiego w bezkrólewiu 1733 roku w: Rozprawy z dziejów XVIII wieku // In: Rozprawy z dziejów XVIII wieku. Z dziejów komunikacji socjalnej epoki nowożytnej / red. Jerzy Wojtowicz. Toruń: Wyd. Uniw. M. Kopernika. - s. 63-78.

125. Postawa „familii” Czartoryskich w bezkrólewiu 1733 roku z perspektywy Wiednia // In: Między wielką polityką a szlacheckim partykularzem. Studia z dziejów nowożytnej Polski i Europy ku czci Profesora Jacka Staszewskiego / red. Kazimierz Wajda [i in.]. Toruń: Wyd. Uniw. M. Kopernika w Toruniu. -s. 275-283.

126. Toruńskie sympozjum „Szlachta i ziemiaństwo na Pomorzu w dobie nowożytnej w XVI-XX wieku". Zap. Hist. T. 58 z. 1 s. 179-181.

128. Wokół „Epistolarum familiarum” Stanisława Konarskiego z 1733 roku. Wiek Oświec. T. 9 s. 65-72.

129. Wstęp // In: Szlachta i ziemiaństwo na Pomorzu w dobie nowożytnej XVI-XX wieku. (Przemiany struktur wewnętrznych). Materiały sympozjum w Toruniu, 9 IV 1992 r. / red. [...]. - Toruń: Tow. Nauk. w Toruniu; Instytut Historii PAN. - s. 3-6.

130. Zmiany w elicie władzy Prus Królewskich w XV-XVIII wieku (czynniki awansu, trwania i upadku) // In: Szlachta i ziemiaństwo na Pomorzu w dobie nowożytnej XVI-XX wieku. (Przemiany struktur wewnętrznych). Materiały sympozjum w Toruniu, 9 IV 1992 r. / red. [...]. - Toruń: Tow. Nauk. w Toruniu; Instytut Historii PAN. - s. 7-29. [Wspólnie z Krzysztofem Mikulskim]

131. Rec. - [Dwieście] 200 lat Konstytucji 3 Maja. Materiały z konferencji naukowej [Bydgoszcz, 24-25 IV 1991 r.] / red. Marian Pawlak, Bydgoszcz: 1992. - Kwart. Hist. R. 100 nr 1 s. 143-145.

132. Rec. - Leitgeber Sławomir: Potuliccy. Londyn, 1990. - Zap. Hist. T. 58 z. 4 s. 163-164 . 
133. Rec. - Saratowicz Anna: Pałac Przebendowskich. Warszawa, 1990. - Zap. Hist. T. 58 z. $2 / 3$ s. 107-109.

134. Rec. - Studia Pelplińskie T. 18: 1987. - Zap. Hist. T. 58 z. 1 s. 129-130.

135. Red. - Szlachta i ziemiaństwo na Pomorzu w dobie nowożytnej XVI-XX wieku. (Przemiany struktur wewnętrznych). Materiały sympozjum w Toruniu, 9 IV 1992 r. Toruń: Tow. Nauk. w Toruniu, Instytut Historii PAN. - 147 s., [2] s.

136. Adam Stanisław Grabowski (1698-1766): biskup, polityk, mecenas. - Olsztyn: OBN. - 166 s., [2] s., tabl. 1.

137. Biskupi chełmińscy epoki kontrreformacji i wczesnego oświecenia (1574-1772) // In: Z przeszłości diecezji chełmińskiej 1243-1992. Materiały konferencji naukowej w Toruniu, 6 XI 1993 r. / red. Marian Biskup. - Toruń: Tow. Nauk. w Toruniu. - s. 31-51.

138. Dwaj pijarzy Konarscy. Z tajemnic publicystyki politycznej bezkrólewia 1733 roku. Kwart. Hist. T. $101 \mathrm{nr} 1$ s. 81-90.

139. Episkopat rzymskokatolicki doby saskiej. Aktywność w życiu publicznym Rzeczypospolitej // In: Między monarchią a demokracją. Studia z dziejów Polski XV-XVIII wieku / red. Anna Sucheni-Grabowska, Małgorzata Żaryn. - Warszawa: Wyd. Sejmowe. - s. 332-376.

140. Geret Samuel Luter (1730-1797), rezydent Tor. w W-wie, rajca i burmistrz tor. // In: Słow. biogr. Pom. Nadwiśl. T. 2 G-K. Gdańsk. - s. 35-36.

141. Giller Gotfryd (1709-1793), burmistrz tor. // In: Słow. biogr. Pom. Nadwiśl. T. 2 G-K. Gdańsk. - s. 56-57.

142. Giering Antoni (1685-1759), burmistrz tor. // In: Słow. biogr. Pom. Nadwiśl. T. 2 G-K. Gdańsk. - s. 48.

143. Goltz (Golcz) August Stanisław h. własnego (1725-1795), gen. mrj, marszałek konfederacji dysydenckiej w Tor. // In: Słow. biogr. Pom. Nadwiśl. T. 2 G-K. Gdańsk. - s. 77-78.

144. Goltz (Golcz) Jerzy Wilhelm h. własnego (1721-1767), gen. lejtnant, marszałek konfederacji dysydenckiej w Tor. // In: Słow. biogr. Pom. Nadwiśl. T. 2 G-K. Gdańsk. - s. 78.

145. Gostomski Andrzej Konrad h. Nałęcz (przed 1728-1785). // In: Słow. biogr. Pom. Nadwiśl. T. 2 G-K. Gdańsk. - s. 81-82.

146. Gotartowski Ignacy h. Leliwa (1724-1777). // In: Słow. biogr. Pom. Nadwiśl. T. 2 G-K. Gdańsk. - s. 83.

147. Grabowski Adam Stanisław h. Zbiświcz (1698-1766), bp chełm., kujawski, warmiński. // In: Słow. biogr. Pom. Nadwiśl. T. 2 G-K. Gdańsk. - s. 94-95.

148. Grabowski Jan Michał h. Zbiświcz (ok. 1703-1770), kasztelan elbląski. // In: Słow. biogr. Pom. Nadwiśl. T. 2 G-K. Gdańsk. - s. 97.

149. Gralewski Franciszek h. Sulima (1713-1783), poseł na sejmy, kanonik chełm. // In: Słow. biogr. Pom. Nadwiśl. T. 2 G-K. Gdańsk. - s. 104-105. 
150. Grąbczewski Tomasz h. Nałęcz (zm. 1758), kasztelan chełm. // In: Słow. biogr. Pom. Nadwiśl. T. 2 G-K. Gdańsk. - s. 107-108.

151. Hauenstein Jan Fryderyk (zm. 1736), księgarz i rajca tor. // In: Słow. biogr. Pom. Nadwiśl. T. 2 G-K. Gdańsk. - s. 169-170.

152. Jaster Szymon (1713-1772), rajca tor. // In: Słow. biogr. Pom. Nadwiśl. T. 2 G-K. Gdańsk. - s. 307-308.

153. Jezierski Michał Lewald h. Rogala (ok. 1724-1785), podwojewodzi i chorąży pom. // In: Słow. biogr. Pom. Nadwiśl. T. 2 G-K. Gdańsk. - s. 317.

154. Konarski Stanisław h. Ossoria (zm. 1625), woj. malborski. // In: Słow. biogr. Pom. Nadwiśl. T. 2 G-K. Gdańsk. - s. 430.

155. Konarski Stanisław h. Ossoria (Kolczyk) (ok. 1690-1757), kasztelan chełm. // In: Słow. biogr. Pom. Nadwiśl. T. 2 G-K. Gdańsk. - s. 430-431.

156. Konfederacja krakowska Teodora Lubomirskiego z początków bezkrólewia 1733 roku a polityka Austrii wobec Rzeczypospolitej // In: Trudne stulecia. Studia z dziejów XVII i XVIII wieku ofiarowane Profesorowi Jerzemu Michalskiemu w siedemdziesiątą rocznicę urodzin / red. Łukasz Kądziela, Wojciech Kriegseisen, Zofia Zielińska. Warszawa: Wyd. Nauk. Semper. - s. 46-54.

157. Kretkowski Zygmunt h. Dołęga (po 1702?-1766), woj. chełm. // In: Słow. biogr. Pom. Nadwiśl. T. 2 G-K. Gdańsk. - s. 504-505.

158. Kruszyński Antoni h. Prawdzic (1706-1774), kasztelanic gd. // In: Słow. biogr. Pom. Nadwiśl. T. 2 G-K. Gdańsk. - s. 517.

159. Kruszyński Antoni h. Prawdzic (1764-po 1812), oficer, powstaniec kościuszkowski i z 1807. // In: Słow. biogr. Pom. Nadwiśl. T. 2 G-K. Gdańsk. - s. 517-518.

160. Kruszyński Konstanty h. Prawdzic (1751-1818), działacz polit. i oświatowy. // In: Słow. biogr. Pom. Nadwiśl. T. 2 G-K. Gdańsk. - s. 518-519.

161. Sapieha Piotr Paweł h. Lis (1701-1771), stolnik litewski, wojewoda smoleński. // In: Pol. słow. biogr. T. 35. Warszawa. - s. 149-154.

[Wspólnie z Władysławem Konopczyńskim]

162. Sarnacki Antoni h. Nałęcz (ok. 1722-1787), skarbnik bielski, chorąży malborski, konfederat barski. // In: Pol. słow. biogr. T. 35. Warszawa. - s. 200-203.

163. Schack (Szak, Schach) von Wittenau (z Witenowa) Karol Albrecht (Wojciech) h. własnego (1711-1782?), generał major, działacz dysydencki. // In: Pol. słow. biogr. T. 35. Warszawa. - s. 390-392.

164. Schmid (Schmied, Schmidt, Schmieden von Schmiedenbach) Jerzy (1629-1697), burmistrz Torunia. // In: Pol. słow. biogr. T. 35. Warszawa. - s. 535-536.

165. Schmidt Karol Franciszek (ok. 1712-1769), starosta brodnicki, urzędnik skarbowy, dyrektor budowli królewskich. // In: Pol. słow. biogr. T. 35. Warszawa. - s. 543-546.

166. Z historii dekanatu golubskiego // In: Diecezja toruńska. Historia i teraźniejszość. T. 7 Dekanat golubski / red. ks. Stanisław Kardasz. - Toruń: Kuria Diecezjalna w Toruniu - s. 5-12.

167. Z historii dekanatu wąbrzeskiego // In: Diecezja toruńska. Historia i teraźniejszość. T. 18 Dekanat wąbrzeski / red. ks. Stanisław Kardasz. - Toruń: Kuria Diecezjalna w Toruniu - s. 5-10. 
168. Rec. - Naworski Zbigniew: Sejmik generalny Prus Królewskich 1569-1772. Organizacja i funkcjonowanie na tle systemu zgromadzeń stanowych prowincji. Toruń, 1992. - Kwart. Hist. R. $101 \mathrm{nr} 3$ s. 86-88.

1995

169. Elity polityczne wielkich miast Prus Królewskich w dobie Oświecenia (1733-1772) // In: Prace historycznoliterackie T. 17: Elity mieszczańskie i szlacheckie Prus Królewskich i Kujaw w XIV-XVIII wieku / red. Jacek Staszewski. - Toruń: Wyd. Uniw. M. Kopernika w Toruniu. - s. 119-137.

170. Sarmata oświecony - życie i poglądy polityczno-pedagogiczne ostatniego wojewody chełmińskiego Franciszka Stanisława Czapskiego // In: Oświecenie - Kultura - Myśl / red. Julian Platt. - Gdańsk: Uniw. Gdański. - s. 319-342.

171. Z historii dekanatu chełmżyńskiego // In: Diecezja toruńska. Historia i teraźniejszość. T. 5 Dekanat chełmżyński / red. ks. Stanisław Kardasz. - Toruń: Wyd. Konserwatora Diecezjalnego; Kuria Diecezjalna w Toruniu. - s. 8-17.

172. Z historii dekanatu lubawskiego // In: Diecezja toruńska. Historia i teraźniejszość. T. 11 Dekanat lubawski / red. ks. Stanisław Kardasz. - Toruń: Wyd. Konserwatora Diecezjalnego; Kuria Diecezjalna w Toruniu. - s. 7-15.

[Wspólnie z Marią Wielgus]

173. Z historii dekanatów toruńskich // In: Diecezja toruńska. Historia i teraźniejszość. T. 15/16/17 Dekanaty toruńskie I, II i III / red. ks. Stanisław Kardasz. - Toruń: Wyd. Diecezjalne. - s. 9-34.

[Wspólnie ze Zbigniewem Nawrockim, Markiem Rubnikowiczem i Ryszardem Sudzińskim]

1996

174. Jerzy Wojtowicz (24 X 1924-7 IV 1996). Kwart. Hist. R. 103 nr 3 s. 163-165. [Wspólnie z Kazimierzem Maliszewskim]

175. Miasto w dobie Augusta III (1733-1763) // In: Historia Torunia / red. Marian Biskup. T. 2 cz. 3 Między barokiem a oświeceniem (1660-1793). - Toruń: Wyd. Tow. Nauk. w Toruniu. - s. 206-246.

176. Schultz Szymon (Simon) (ok. 1630-1708), burmistrz toruński. // In: Pol. słow. biogr. T. 36. Warszawa. - s. 35.

177. Schwerdtmann (Schwertman, Szwertman) Kazimierz Leon (1693-1760), burmistrz Torunia. // In: Pol. słow. biogr. T. 36. Warszawa. - s. 73-74.

178. Toruń między szwedzkim potopem a wojną północną (1660-1699) // In: Historia Torunia / red. Marian Biskup. T. 2 cz. 3 Między barokiem a oświeceniem (1660-1793). - Toruń: Wyd. Tow. Nauk. w Toruniu. - s. 96-137.

179. Toruń w okresie reform Rzeczypospolitej i zagrożenia pruskiego (1764-1793) // In: Historia Torunia / red. Marian Biskup. T. 2 cz. 3 Między barokiem a oświeceniem (1660-1793). - Toruń: Wyd. Tow. Nauk. w Toruniu. - s. 247-298.

180. Upadek miasta w dobie wojny północnej (1700-1718) // In: Historia Torunia / red. Marian Biskup. T. 2 cz. 3 Między barokiem a oświeceniem (1660-1793). - Toruń: Wyd. Tow. Nauk. w Toruniu. - s. 138-174. 
181. U początków katolickiego oświecenia w Polsce? Z działalności kościelnej biskupów Andrzeja Stanisława Załuskiego i Adama Stanisława Grabowskiego // In: Między Barokiem a Oświeceniem. Nowe spojrzenie na czasy saskie / red. Krystyna Stasiewicz, Stanisław Achremczyk. - Olsztyn: OBN. - s. 181-187.

182. W cieniu głębokich konfliktów wyznaniowych (1719-1732) // In: Historia Torunia / red. Marian Biskup. T. 2 cz. 3 Między barokiem a oświeceniem (1660-1793). - Toruń: Wyd. Tow. Nauk. w Toruniu. - s. 175-205.

183. Z historii dekanatu chełmińskiego // In: Diecezja toruńska. Historia i teraźniejszość. T. 4 Dekanat chełmiński / red. ks. Stanisław Kardasz. - Toruń: Kuria Diecezjalna w Toruniu - s. 8-19.

184. Z historii ziem dekanatu bierzgłowskiego // In: Diecezja toruńska. Historia i teraźniejszość. T. 2 Dekanat bierzgłowski / red. ks. Stanisław Kardasz. - Toruń: Kuria Diecezjalna w Toruniu - s. 9-16.

[Wspólnie z Markiem Rubnikowiczem]

185. Rec. - Bömelburg Hans-Jürgen: Zwischen polnischer Ständgesellschaft und preussischen Obrigkeitsstaat. Vom Königlichen Preussen zu Westpreussen (1756-1806). München, 1995. - Kwart. Hist. R. 103 nr 2 s. 90-93.

186. Rec. - Cielak Edmund: Stanisław Leszczyński. Wrocław, 1994. - Wiek Oświec. T. 12 s. $149-155$.

187. Rec. - Historia Gdańska / red. Edmund Cieślak T. 3 Vol. 1: 1655-1793. Gdańsk, 1993. - Zap. Hist. T. 61 z. 4 s. 138-141.

188. Rec. - Kriegseisen Wojciech: Ewangelicy polscy i litewscy w epoce saskiej (1696-1763). Sytuacja prawna, organizacja i stosunki międzywyznaniowe. Warszawa, 1996. - Kwart. Hist. R. $103 \mathrm{nr} 4$ s. 147-149.

\section{7}

189. Historyk Torunia i Europy. Wspomnienie o profesorze Jerzym Wojtowiczu. Rocz. Tor. T. 24 s. $245-252$. [Wspólnie z Kazimierzem Maliszewskim]

190. Kwestia dysydencka w Rzeczypospolitej doby bezkrólewia 1733 roku. Zap. Hist. T. 62 z. 4 s. $45-67$.

191. Leski Wojciech Stanisław h. Gończy (1702-1758), opat pelp., bp chełm. // In: Słow. biogr. Pom. Nadwiśl. T. 3 L-P. Gdańsk. - s. 49-50.

192. Lipiński Jakub Szur h. własnego (ok. 1730-1797), pisarz grodzki pom., konfederat barski. // In: Słow. biogr. Pom. Nadwiśl. T. 3 L-P. Gdańsk. - s. 67-68.

193. Lipiński Onufry Szur h. własnego (ok. 1762-po 1807), org. pospolitego ruszenia 1806-7, ziemianin. // In: Słow. biogr. Pom. Nadwiśl. T. 3 L-P. Gdańsk. - s. 68.

194. Lniski Michał Władysław h. Ostoja (1723-1777), sądowy ziemski tczewski, podwojewodzi pom., konfederat barski. // In: Słow. biogr. Pom. Nadwiśl. T. 3 L-P. Gdańsk. - s. 74-75.

195. Marszan (Marszon) Szymon (?-1774), kupiec i rajca tor. // In: Słow. biogr. Pom. Nadwiśl. T. 3 L-P. Gdańsk. - s. 164-165. 
196. Meisner Jakub (1678-1740), burmistrz tor. // In: Słow. biogr. Pom. Nadwiśl. T. 3 L-P. Gdańsk. - s. 168.

197. Mielcarski Szymon (1714-1771), poczmistrz i burmistrz tor. // In: Słow. biogr. Pom. Nadwiśl. T. 3 L-P. Gdańsk. - s. 208-209.

198. Mostowski Paweł h. Dołęga (ok. 1721-1781), woj. pom. // In: Słow. biogr. Pom. Nadwiśl. T. 3 L-P. Gdańsk. - s. 260-262.

199. Nałęcz Michał (1691-1761), burmistrz tor. // In: Słow. biogr. Pom. Nadwiśl. T. 3 L-P. Gdańsk. - s. 291.

200. Narzymski Jakub h. Dołęga (1690-1759), woj. pom. // In: Słow. biogr. Pom. Nadwiśl. T. 3 L-P. Gdańsk. - s. 296.

201. Oloff Efraim (1715-1766), rajca tor. // In: Słow. biogr. Pom. Nadwiśl. T. 3 L-P. Gdańsk. - s. 356-357.

202. Owidzki Jakub h. Dołęga (? - przed 1774), regent grodzki pom. // In: Słow. biogr. Pom. Nadwiśl. T. 3 L-P. Gdańsk. - s. 374.

203. Pawłowski Mikołaj h. Półkozic (1694-1782), sędzia ziemski człuchowski. // In: Słow. biogr. Pom. Nadwiśl. T. 3 L-P. Gdańsk. - s. 400-401.

204. Piwnicki Jan Franciszek h. Lubicz (?-1733), podwojewodzi chełm. // In: Słow. biogr. Pom. Nadwiśl. T. 3 L-P. Gdańsk. - s. 435.

205. Piwnicki Kazimierz h. Lubicz (?-1749), sędzia ziemski chełm. // In: Słow. biogr. Pom. Nadwiśl. T. 3 L-P. Gdańsk. - s. 435-436.

206. Piwnicki Konstanty Kazimierz h. Lubicz (ok. 1720-1799), podwojewodzi chełm. // In: Słow. biogr. Pom. Nadwiśl. T. 3 L-P. Gdańsk. - s. 436-437.

207. Piwnicki Walerian Józef h. Lubicz (ok. 1720-1799), miecznik ziem pruskich, członek Kom. Skarbu Koronnego. // In: Słow. biogr. Pom. Nadwiśl. T. 3 L-P. Gdańsk. - s. 436-437.

208. Pląskowski Fabian Franciszek h. Oksza (1705-1784), bp sufragan chełm. // In: Słow. biogr. Pom. Nadwiśl. T. 3 L-P. Gdańsk. - s. 440. [Wspólnie z Bogusławem Dygdałą]

209. Politycy gdańscy doby Oświecenia. Szkic do portretu zbiorowego // In: Mieszczaństwo gdańskie. Sesja naukowa 21-23.11.1996 / red. Stanisław Salmonowicz. - Gdańsk: Nadbałtyckie Centr. Kult.; Gdańskie Tow. Nauk. - s. 143-153.

210. Potulicki Jan Jakub h. Grzymała (ok. 1652-1726), podkom. pom., woj. brzeski kujawski. // In: Słow. biogr. Pom. Nadwiśl. T. 3 L-P. Gdańsk. - s. 477-478.

210. Praetorius (Prätorius) Nataniel (1722-1791), burmistrz tor. // In: Słow. biogr. Pom. Nadwiśl. T. 3 L-P. Gdańsk. - s. 485-486.

211. Pruszak Józef Bernard h. Leliwa (?-1774), kasztelan gd. // In: Słow. biogr. Pom. Nadwiśl. T. 3 L-P. Gdańsk. - s. 494.

212. Przebendowski Ignacy h. Kuna (ok. 1733/4-1791), woj. pom., poczmistrz generalny Rzeczypospolitej, marszałek Rady Nieustającej. // In: Słow. biogr. Pom. Nadwiśl. T. 3 L-P. Gdańsk. - s. 496-498.

213. Przebendowski Jakub h. Kuna (?-1724), płk, kasztelan elbl. // In: Słow. biogr. Pom. Nadwiśl. T. 3 L-P. Gdańsk. - s. 498. 
214. Przebendowski Jakub h. Kuna (przed 1724-1787), kasztelan elbl. // In: Słow. biogr. Pom. Nadwiśl. T. 3 L-P. Gdańsk. - s. 498-499.

215. Przebendowski Jan Jerzy h. Kuna (1639-1729), kasztelan chełm., woj. malb., podskarbi w. kor. // In: Słow. biogr. Pom. Nadwiśl. T. 3 L-P. Gdańsk. - s. 499-500.

216. Przebendowski Józef Antoni h. Kuna (?-1775), chor. pom. // In: Słow. biogr. Pom. Nadwiśl. T. 3 L-P. Gdańsk. - s. 500-501.

217. Reyher Jerzy Adam (1724-1800), burmistrz tor. // In: Słow. biogr. Pom. Nadwiśl. T. 4 R-Ż. Gdańsk. - s. 58-59.

218. Rogaliński Kasper h. Łodzia (ok. 1725-1788), woj. inflancki. // In: Słow. biogr. Pom. Nadwiśl. T. 4 R-Ż. Gdańsk. - s. 80.

219. Rybiński Jacek Józef h. Radwan (1701-1782), opat oliwski. // In: Słow. biogr. Pom. Nadwiśl. T. 4 R-Ż. Gdańsk. - s. 118-119.

220. Sarnacki Antoni h. Nałęcz (ok. 1722-1787), skarbnik bielski, chorąży malborski, konfederat barski. // In: Słow. biogr. Pom. Nadwiśl. T. 4 R-Ż. Gdańsk. - s. 146-147.

221. Skórzewski Stanisław h. Ogończyk (1700-1761), kasztelan elbląski i chełm. // In: Słow. biogr. Pom. Nadwiśl. T. 4 R-Ż. Gdańsk. - s. 227-228.

222. Sienieński Dominik h. Dębno (zm. 1743), biskup tytularny maronicki, kanonik warmiński, gnieźnieński i krakowski, oficjał gdański. // In: Pol. słow. biogr. T. 37. Warszawa. - s. $172-173$.

223. Sikorski Jan Teofil h. Cietrzew (zm. 1740), pisarz grodzki pomorski, poseł na sejmy. // In: Pol. słow. biogr. T. 37. Warszawa. - s. 435-436.

224. Stoliński Melchior Kalkstein h. Trzy Pasy (Kos) (zm. 1762), chorąży chełm. // In: Słow. biogr. Pom. Nadwiśl. T. 4 R-Ż. Gdańsk. -s. 273.

225. Thomas Gerhard (1650-1725), burmistrz toruński. // In: Słow. biogr. Pom. Nadwiśl. T. 4 R-Ż. Gdańsk. - s. 368.

226. Toruń wobec Komisji Skarbu Koronnego w początkach panowania Stanisława Augusta (1764-1768) // In: Gospodarka - społeczeństwo - ustrój. Studia dedykowane Profesorowi Stefanowi Cackowskiemu w siedemdziesiątą rocznicę urodzin i czterdziestą piątą rocznicę pracy naukowej / red. Krzysztof Mikulski. - Toruń. Acta Univ. N. Copern., Hist. nr 30 s. 81-89.

227. Tuchołka Piotr h. Korzbok (zm. 1764), podkomorzy malborski. // In: Słow. biogr. Pom. Nadwiśl. T. 4 R-Ż. Gdańsk. - s. 384.

228. Wilczewski Franciszek h. Trzy Radła (1716-po 1793), podkomorzy wiski, poseł na sejmy. // In: Słow. biogr. Pom. Nadwiśl. T. 4 R-Ż. Gdańsk. - s. 449-450.

229. Wilczewski Walenty Kazimierz h. Trzy Radła (zm. 1771), sędzia ziemski malborski, marszałek konfederacji barskiej woj. malborskiego. // In: Słow. biogr. Pom. Nadwiśl. T. 4 R-Ż. Gdańsk. - s. 450.

230. Wolszlegier (Wollschläger) Józef h. Bełty (ok. 1750-1822?), landrat chojnicki. // In: Słow. biogr. Pom. Nadwiśl. T. 4 R-Ż. Gdańsk. - s. 482-483.

231. Wydatki biskupa Adama Stanisława Grabowskiego podczas pobytu w Gdańsku w latach 1737-1738 // In: Ludzie, kontakty, kultura XVI-XVIII wieku. Prace ofiarowa- 
ne Profesor Marii Boguckiej / red. Jerzy Kowecki, Janusz Tazbir. - Warszawa: Wyd. Nauk. Semper. - s. 111-117.

232. Zboiński Jakub Hiacynt h. Ogończyk (zm. 1755), kasztelan elbląski. // In: Słow. biogr. Pom. Nadwiśl. T. 4 R-Ż. Gdańsk. - s. 520-521.

232. Z historii dekanatu grudziądzkiego // In: Diecezja toruńska. Historia i teraźniejszość. T. 8 Dekanat grudziądzki / red. ks. Stanisław Kardasz. - Toruń: Kuria Diecezjalna w Toruniu. - s. 8-21.

234. Z historii dekanatu lembarskiego // In: Diecezja toruńska. Historia i teraźniejszość. T. 9 Dekanat lembarski / red. ks. Stanisław Kardasz. - Toruń: Kuria Diecezjalna w Toruniu. - s. 6-13.

235. Z historii dekanatu łasińskiego // In: Diecezja toruńska. Historia i teraźniejszość. T. 12 Dekanat łasiński / red. ks. Stanisław Kardasz. - Toruń: Kuria Diecezjalna w Toruniu. - s. 6-15.

236. Z historii dekanatu radzyńskiego // In: Diecezja toruńska. Historia i teraźniejszość. T. 14 Dekanat radzyński / red. ks. Stanisław Kardasz. - Toruń: Kuria Diecezjalna w Toruniu. - s. 6-18.

\section{8}

237. Brodnica w dobie Rzeczypospolitej szlacheckiej (1466-1772) // In: Brodnica. Siedem wieków miasta / red. [...]. - Brodnica: Rada Miejska. - s. 107-158.

238. Cocchi (Koki) Jan (Giovanni) Baptysta (1701-1759), architekt i rajca tor. // In: Tor. słow. biogr. T. 1. Toruń. - s. 51-52.

239. Donepe Antoni (1606-1663), burmistrz tor. // In: Tor. słow. biogr. T. 1. Toruń. - s. 83-84 .

240. Dutkiewicz Stanisław (zm. 1754), kupiec i rajca tor. // In: Tor. słow. biogr. T. 1. Toruń. - s. 87.

241. Klosmann Christian (1697-1774), burmistrz i polityk tor. // In: Tor. słow. biogr. T. 1. Toruń. - s. 135-139.

242. Meisner Jakub (1678-1740), burmistrz tor. // In: Tor. słow. biogr. T. 1. Torun. s. 172.

243. Mielcarski Szymon (1714-1771), poczmistrz i burmistrz tor. // In: Tor. słow. biogr. T. 1. Toruń. - s. 177-178.

244. Nałęcz Michał (1691-1761), rajca i burmistrz tor. // In: Tor. słow. biogr. T. 1. Toruń. - s. 182.

245. Przedmowa // In: Brodnica. Siedem wieków miasta / red. [...]. Brodnica: Rada Miejska. - s. 7-11.

246. Skarbek Franciszek h. Abdank (zm. 1749), wojewoda łęczycki. // In: Pol. słow. biogr. T. 38. Warszawa. - s. 7-8.

[Wspólnie z Jarosławem Dumanowskim]

247. Skarbek Jan h. Abdank (ok. 1710-1772), kasztelan inowrocławski. // In: Pol. słow. biogr. T. 38. Warszawa. - s. 17-19.

[Wspólnie z Jarosławem Dumanowskim] 
248. Skórzewski Andrzej h. Drogosław (zm. 1726?), generał-major wojsk kor., poseł na sejmy. // In: Pol. słow. biogr. T. 38. Warszawa. - s. 361-363.

249. Skórzewski Michał h. Drogosław (1707-1789), podkomorzy poznański. // In: Pol. słow. biogr. T. 38. Warszawa. - s. 371-373.

250. Skórzewski Stanisław h. Drogosław (1700-1761), kasztelan chełmiński, generał lejtnant wojsk. kor. // In: Pol. słow. biogr. T. 38. Warszawa. - s. 378-379.

251. Schmid (Schmied, Schmidt, Schmieden von Schmiedenbach) Jerzy (Georg) (1629-1697), burmistrz tor. // In: Tor. słow. biogr. T. 1. Toruń. - s. 218.

252. Schoenwald (Schönwaldt) Reinhold Teodor (1677-1735), piwowar i burmistrz tor. // In: Tor. słow. biogr. T. 1. Torun. - s. 220-221.

253. Szlachta polska Prus Królewskich wobec reform wewnętrznych Rzeczypospolitej w początkach panowania Stanisława Augusta (1764-1768) // In: Szlachta, społeczeństwo, państwo między Warmią a Rugią w XVIII-XX wieku / red. Mieczysław Jaroszewicz, Włodzimierz Stępiński. - Szczecin-Słupsk: Muzeum Pomorza Środkowego. - s. $227-242$.

254. Toruń w czasach saskich // In: Toruń i miasta ziemi chełmińskiej na rysunkach Jerzego Fryderyka Steinera z pierwszej połowy XVIII wieku (tzw. Album Steinera) / red. Marian Biskup. - Toruń: Tow. Nauk. w Toruniu. - s. 15-24.

255. Z historii dekanatu brodnickiego // In: Diecezja toruńska. Historia i teraźniejszość. T. 2 Dekanat brodnicki / red. ks. Stanisław Kardasz. - Toruń: Kuria Diecezjalna w Toruniu. - s. 6-20.

256. Z historii dekanatu nowomiejskiego // In: Diecezja toruńska. Historia i teraźniejszość. T. 13 Dekanat nowomiejski / red. ks. Stanisław Kardasz. - Toruń: Kuria Diecezjalna w Toruniu. - s. 7-18.

257. Rec. - Klemp Aleksander: Protestanci w dobrach prywatnych w Prusach Królewskich od drugiej połowy XVII do drugiej połowy XVIII wieku. Gdańsk, 1994. - Zap. Hist. T. 63 z. 2 s. $217-219$.

258. Rec. - Żochowski Henryk, Die Seelsorge im Ermland unter Bischof Christoph Andreas Johann Szembek: 1724-1740. Münster/Westf., 1993. - Zap. Hist. T. 63 z. 1 s. 183-184 .

259. Red. - Brodnica. Siedem wieków miasta / Brodnica: Rada Miejska. - 403 s., [1] s., tabl. 60 , ilustr., mapy.

1999

260. Biskupi chełmińscy i kujawscy doby potrydenckiej i ich rola w życiu Prus Królewskich (1569-1772). Stud. Pelpl. T. 29 s. 103-122.

261. Kilka uwag wstępnych [do artykułu: S.K. Wałęga: Perypetie toruńskie i gdańskie na sejmiku generalnym grudziądzkim w marcu 1764 roku]. Rocz. Tor. T. 26 s. 131-134.

262. U początków polityki wewnętrznej Stanisława Augusta w latach 1764-1768 (na przykładzie Prus Królewskich). Wiek Oświec. T. 15 s. 111-134. 
2000

263. Borkowski Albert (1686-1757), burmistrz tor. // In: Tor. słow. biogr. T. 2. Toruń. s. 44-46.

264. Die Politik Österreichs gegenüber Polen während des Interregnums im Jahre 1733 // In: Polen und Österreich im 18. Jahrhundert / hrsg. v. Walter Leitsch, Stanisław Trawkowski unter Mitwirkung v. Wojciech Kriegseisen. - Warszawa: Wyd. Nauk. „Semper". - s. 123-143.

265. Geret Samuel Luther (1730-1797). // In: Tor. słow. biogr. T. 2. Toruń. - s. 90-91.

266. Grabowscy w Prusach Królewskich i Wielkopolsce w XVIII wieku jako przykład kariery rodziny szlacheckiej. Misc. Hist.-Arch. T. 11 s. 119-131.

267. Lustracja województw Prus Królewskich 1765. T. 1: Województwo pomorskie. Cz. 1: Powiaty pucki i mirachowski. - Toruń: Tow. Nauk. w Toruniu. - XLI s., 196 s., tabl. 1, mapa.

268. Oloff Efraim syn (1715-1766), rajca tor. // In: Tor. słow. biogr. T. 2. Toruń. - s. 185$-186$.

269. Praetorius (Prätorius) Nataniel (Nathanael) (1722-1791), burmistrz toruński. // In: Tor. słow. biogr. T. 2. Torun. - s. 203-204.

270. Schwerdtmann Kazimierz Leon (Schwertmann, Szwertman) (1693-1760), burmistrz tor. // In: Tor. słow. biogr. T. 2. Toruń. -s. 210-212.

271. Steiner Christian Friedrich (Krystian Fryderyk) (1722-1783), sekretarz i rajca tor. // In: Tor. słow. biogr. T. 2. Torun. - s. 225-226.

272. Wojtowicz Jerzy (1924-1996) // In: Działacze Towarzystwa Naukowego w Toruniu / red. Marian Biskup, Andrzej Giziński. T. 2. - Toruń: Tow. Nauk. w Toruniu. - s. 175-183. [Wspólnie z Kazimierzem Maliszewskim]

273. Z saskich zabiegów o koronę polską w 1764 roku. Dwuznaczna misja w Rzeczypospolitej generała Jerzego Wilhelma Goltza. Zap. Hist. T. 65 z. 3/4 s. 91-106.

274. Zmienne losy kupca i przemysłowca Chrystiana Andrzeja Ruttiga (z burzliwych początków toruńskiego kapitalizmu w XVIII wieku). Rocz. Tor. T. 27 s. 113-136.

275. Rec. - Czeppe Maria: Kamaryla Pana z Dukli. Kształtowanie się obozu politycznego Jerzego Augusta Mniszcha 1750-1763. Warszawa, 1998. - Wiek Oświec. T. 16 s. 184$-191$.

276. Rec. - Kasabuła Tadeusz: Ignacy Massalski biskup wileński. Lublin, 1998. - Zap. Hist. T. 65 z. 2. s. $199-201$.

277. Rec. - Prusy Książęce i Prusy Królewskie w XVI-XVIII wieku / red. Jacek Wijaczka. Kielce, 1997. - Zap. Hist. T. 65 z. 1 s. 181-183.

2001

278. Badania Stanisława Salmonowicza nad historią Torunia i Pomorza // In: Historia integra. Studia z historii państwa i prawa, dziejów kultury, religii i oświaty epoki nowożytnej. Księga pamiątkowa ofiarowana Prof. Stanisławowi Salmonowiczowi w siedemdziesięciolecie urodzin / red. Danuta Janicka, Ryszard Łaszewski. - Toruń: Tow. Nauk. Organizacji i Kierownictwa „Dom Organizatora”. - s. 15-17. 
279. Posłowie gdańscy na ostatnich sejmikach generalnych Prus Królewskich z lat 1764-1767 // In: Gdańsk - Polska - Europa. Praca zbiorowa ofiarowana profesorowi doktorowi habilitowanemu Władysławowi Zajewskiemu w siedemdziesiątą rocznicę urodzin / red. Zdzisław Kropidłowski. - Gdańsk: Pomorskie Towarzystwo Filozoficzno-Teologiczne: Fundacja Promocji i Rozwoju „Ekspert”. - s. 55-63.

280. Prusy Królewskie wobec reformy Trybunału Koronnego z 1764 roku. Zap. Hist. T. 66 z. 4 s. $69-83$.

281. Rezydencje magnackie w Prusach Królewskich w XVIII wieku // In: Rezydencje w średniowieczu i czasach nowożytnych / red. nauk. Edward Opaliński, Tomasz Wiślicz. - Warszawa: Neriton. - s. 125-145.

282. Sokolnicki Piotr Antoni h. Nowina (1683-1758), regimentarz, pułkownik wojsk kor., chorąży poznański. // In: Pol. słow. biogr. T. 40. Warszawa. - s. 88-89.

283. Sołtyk Maciej Aleksander h. własnego (1679-1749), biskup sufragan chełmiński. // In: Pol. słow. biogr. T. 40. Warszawa. - s. 407-409.

284. Szersze tło zabiegów króla Stanisława Augusta o biskupstwo warmińskie dla Ignacego Krasickiego // In: Ignacy Krasicki. Nowe spojrzenie / red. Zbigniew Goliński, Teresa Kostkiewiczowa, Krystyna Stasiewicz. - Warszawa: DiG. - s. 11-27.

\section{2}

285. Antystanisławowska i prosaska publicystyka doby bezkrólewia 1733 roku (dzieła, autorzy, rozpowszechnianie). Kwart. Hist. R. 109 nr 2 s. 41-59.

286. Czarnecki Franciszek Ignacy (1714-1766), urzędnik pocztowy, rajca tor. // In: Tor. słow. biogr. T. 3. Torun. - s. 43-44.

287. Giering Antoni (1685-1759), burmistrz tor. // In: Tor. słow. biogr. T. 3. Toruń. - s. 66$-67$.

288. Giering Jan (Johann) (1688-1766), burmistrz tor. // In: Tor. słow. biogr. T. 3. Toruń. - s. 67-68.

289. Giller Gottfreid (1709-1793), burmistrz tor. // In: Tor. słow. biogr. T. 3. Toruń. - s. 71-72 .

290. Marszan (Marszon) Szymon (zm. 1774), kupiec i rajca tor. // In: Tor. słow. biogr. T. 3. Toruń. - s. 156.

291. Młody magnat na drezdeńskim dworze Augusta Mocnego. Fragment europejskiej podróży Michała Kazimierza Radziwiłła z 1722 roku // In: Stosunki polsko-niemieckie w XVI-XVIII wieku. Materiały konferencji naukowej, Kielce-Szydłowiec, 19-21 października 2000 / red. Jacek Wijaczka. - Kielce: Wydaw. Akademii Świętokrzyskiej. - s. 205-223.

292. Weiss Johan Freidrich (1707-1784), tor. kupiec, mechanik i wynalazca. // In: Tor. słow. biogr. T. 3. Toruń. - s. 240-241.

293. Wojtowicz Jerzy, pseud. Pogodny (1924-1996), historyk, badacz hist. Powszechnej i Pom. Nadwiślańskiego. // In: Słow. biogr. Pom. Nadwiśl. Suplement 2. Gdańsk. s. 308-310.

294. Urzędnicy miejscy Torunia. Spisy 1651-1793. - Toruń: Tow. Nauk. w Toruniu. - 248 s., [1] s. 
295. Zacharyaszewicz (Rabiczka) Grzegorz Dominik (1704-1770), kupiec i ławnik tor. // In: Tor. słow. biogr. T. 3. Toruń. - s. 251-252.

296. Rec. - Palkij Henryk: Sejmy 1736 i 1738 roku. U progu nowej sytuacji politycznej w Rzeczypospolitej. Kraków, 2000. - Kwart. Hist. R. 109 nr 2 s. 161-165.

\section{3}

297. Elity polityczne Prus Królewskich w orbicie wpływów dworu w XVIII wieku // In: Dwór a kraj. Między centrum a peryferiami władzy. Materiały z konferencji naukowej zorganizowanej przez Zamek Królewski na Wawelu, Instytut Historii Uniw. Jagiellońskiego i Instytut Historii Akademii Pedagogicznej w Krakowie, w dniach 2-5 kwietnia 2001 / red. Ryszard Skowron. - Kraków: Zamek Królewski na Wawelu. Państwowe Zbiory Sztuki. - s. 487-507.

298. Jan Ansgary Czapski - droga awansu do magnaterii koronnej w pierwszej połowie XVIII wieku // In: Władza i prestiż. Magnateria Rzeczypospolitej w XVI-XVIII wieku / red. Jerzy Urwanowicz, Ewa Dubas-Urwanowicz, Piotr Guzowski. - Białystok: Wyd. Uniw. w Białymstoku. - s. 465-473.

299. Lustracja województw Prus Królewskich 1765. T. 1: Województwo pomorskie. Cz. 2: Powiaty tczewski, gdański i nowski. - Toruń: Uniw. M. Kopernika w Toruniu; Instytut Historii PAN; Tow. Nauk. w Toruniu. - XXIII s., 188 s., [1] s., tabl. 1, mapa.

300. Pacta conventa Augusta III (Z zabiegów o pozyskanie polskiej opinii szlacheckiej) // In: Między Zachodem a Wschodem. Studia ku czci profesora Jacka Staszewskiego. T. 2 / red. Jarosław Dumanowski, Bogusław Dybaś, Krzysztof Mikulski, Jarosław Porazinski, Stanisław Roszak. - Toruń: Wyd. Adam Marszałek. - s. 159-164.

301. Saskie próby infiltracji środowisk szlacheckich podczas bezkrólewia 1733 roku. Kwart. Hist. R. $110 \mathrm{nr} 4$ s. 47-70.

302. „Toruńczanin” Tobias Bauch - redaktor warszawskiego „Patryoty Polskiego” z 1761 r. Wiek Oświec. T. 19 s. 109-124.

\section{4}

303. Bauch Tobias (1733-po 1762), redaktor „Patryoty Polskiego”. // In: Tor. słow. biogr. T. 4. Toruń. - s. 26-27.

304. Jan Kostrzak (1946-2004). Zap. Hist. T. 69 z. 4 s. 227-228.

305. Między wiernością wobec monarchy, lojalnością wobec państwa i poczuciem wspólnoty wyznaniowej (postawy ewangelickich elit wielkich miast Prus Królewskich w latach 1763-1772) // In: Rzeczpospolita wielu wyznań / red. Adam Kaźmierczyk, Andrzej K. Link-Lenczowski, Mariusz Markiewicz, Krystyn Matwijowski. - Kraków: Księgarnia Akademicka. - s. 155-167.

306. Obserwacje i opinie sasko-polskiego konsyliarza Jana Beniamina Steinhausera o schyłku panowania Augusta III i o elekcji Stanisława Augusta. Kwart. Hist. R. 111 nr 3 s. $45-62$.

307. Piwniccy w ziemi chełmińskiej w XVII-XVIII wieku - nieudane próby kariery urzędniczej // In: Pomorskie rody ziemiańskie w czasach nowożytnych / red. Włodzimierz Jastrzębski. - Toruń: Wyd. Mado. - s. 257-273. 
308. Prowincjonalizm średniej szlachty Prus Królewskich w XVIII wieku. Czy można wierzyć opiniom Józefa Wybickiego // In: Cywilizacja prowincji Rzeczypospolitej szlacheckiej / red. Aleksander Jankowski, Andrzej Klonder. - Bydgoszcz: Wyd. Akademii Bydgoskiej. - s. 131-142.

309. Przygotowania stronników Stanisława Leszczyńskiego do obrony Rzeczypospolitej w bezkrólewiu 1733 roku // In: Między barokiem a oświeceniem. Wojny i niepokoje czasów saskich / red. Krystyna Stasiewicz, Stanisław Achremczyk. - Olsztyn: OBN. - s. 36-47.

310. Reyher Jerzy (Georg) Adam (1724-1800), burmistrz tor. // In: Tor. słow. biogr. T. 4. Torun. - s. 194-195.

311. Rossteuscher Jan (Johann) Salomon (?-1738), kupiec dzierżawca, dóbr miejskich, ławnik staromiejski. // In: Tor. słow. biogr. T. 4. Toruń. - s. 199-200 [Wspólnie z Krzysztofem Mikulskim]

312. Ruttig (Ruttich) Andrzej (Andreas) Christian (ok. 1718/1719-1774), tor. kupiec, manufakturzysta. // In: Tor. słow. biogr. T. 4. Toruń. - s. 208-209.

313. Schultz Szymon (Simon) (1630-1708), burmistrz tor. // In: Tor. słow. biogr. T. 4. Toruń. - s. 215-216.

314. Rec. - Stanisław Leszczyński: król, polityk, pisarz, mecenas. Materiały z europejskiej konferencji naukowej zorganizowanej w 300-lecie urodzin króla Stanisława Leszczyńskiego / red. Alojzy Konior. Leszno, 2001. - Wiek Oświec. T. 20 s. 214-217.

315. Rec. - Wolański Filip: Europa jako punkt odniesienia dla postrzegania przestrzeni geograficznej przez szlachtę polską osiemnastego wieku w świetle relacji podróżniczych i geograficznych. Wrocław, 2002. - Wiek Oświec. T. 20 s. 210-214.

\section{5}

316. Lustracja województw Prus Królewskich 1765. T. 1: Województwo pomorskie. Cz. 3: Powiaty świecki, tucholski i człuchowski. - Toruń: Tow. Naukowe w Toruniu; Instytut Historii PAN. - 169 s., mapa.

317. Prace edytorskie nad lustracjami dóbr królewskich XVI-XVIII w. po półwieczu. Stud. Źródłozn. T. 43 s. 161-171. [Wspólnie z Krzysztofem Chłapowskim]

318. Podskarbi wielki koronny Jan Ansgary Czapski - budowa pozycji społecznej i prestiżu nowego magnata w pierwszej połowie XVIII wieku. Zap. Hist. T. 70 z. 1 s. 27-52.

319. Steiner Christian Friedrich (Fryderyk) (1722-1783), sekretarz i rajca Torunia. // In: Pol. słow. biogr. T. 43. Warszawa. - s. 313-314.

320. Steinhauser (Steinhäuser) Jan (Johann) Beniamin (1692-1767), radca kameralny, pisarz polityczny, bibliofil. // In: Pol. słow. biogr. T. 43. Warszawa. - s. 331-333.

321. Życie codzienne na dworze biskupa warmińskiego Adama Stanisława Grabowskiego w połowie XVIII wieku w świetle ksiąg wydatków // In: Dwory magnackie w XVIII wieku. Rola i znaczenie kulturowe / red. Agata Roćko. - Warszawa: Wyd. DiG. s. 275-294.

322. Rec. - Kurek Jacek: U schyłku panowania Augusta II Sasa. Z dziejów wewnętrznych Rzeczypospolitej (1729-1733). Katowice, 2003. - Kwart. Hist. R. 112 nr 1 s. 185-188. 
323. Rec. - Salmonowicz Stanisław: Prusy Królewskie w XVII-XVIII wieku. Studia z dziejów kultury. Toruń, 2002. - Wiek Oświec. T. 21 s. 249-252.

324. Rec. - Vocelka Karl: Glanz und Untergang der höfischen Welt. Repräsentation, Reform und Reaktion im habsburgischen Vielvölkerstaat. Österreichische Geschichte 1699-1815 / hrsg. v. Herwig Wolfram. Wien, 2001. - Wiek Oświec. T. 21 s. 257-266.

325. Rec. - Zakrzewski Andrzej J.: Stanisława Leszczyńskiego „Idea wiecznego pokoju”. Kraków, 2003. - Wiek Oświec. T. 21 s. 324-329.

\section{6}

326. Fryderycjańskie Prusy w świetle listów sasko-polskiego urzędnika skarbowego J. B. Steinhausera z lat sześćdziesiątych XVIII wieku // In: Nad Bałtykiem, Pregołą i Łyną XVI-XX wiek. Księga pamiątkowa poświęcona Jubileuszowi 50-lecia pracy naukowej Prof. Janusza Jasińskiego / red. Zenona Rondomańska. - Olsztyn: Pracownia Wyd. ElSet. - s. 205-216.

327. Gdańskie wydatki bp. Adama Stanisława Grabowskiego. Pomerania R. 33 nr 5 (387) s. 30-32.

328. Śląskie wątki polskiego bezkrólewia 1733 roku // In: Między Lwowem a Wrocławiem. Księga jubileuszowa Prof. Krystyna Matwijowskiego / red. Bogdan Rok, Jerzy Maroń. - Toruń: Wyd. Adam Marszałek. - s. 617-630.

329. Z działalności kościelnej i politycznej biskupa chełmińskiego Wojciecha Stanisława Leskiego (1702-1758) // In: Ad fontes. Studia ofiarowane Księdzu Prof. Alojzemu Szorcowi w siedemdziesięciolecie urodzin / red. Zoja Jaroszewicz-Pieresławcew, Irena Makarczyk. - Olsztyn: Pracownia Wyd. ElSet. - s. 82-99.

[Wspólnie z Bogusławem Dygdałą]

330. Rec. - Perłakowski Adam: Jan Jerzy Przebendowski jako podskarbi wielki koronny (1703-1729). Kraków, 2004. - Zap. Hist. T. 71 z. 1 s. 177-181.

331. Rec. - Salmonowicz Stanisław: W staropolskim Toruniu XVI-XVIII w. Studia i szkice. Toruń, 2005. - Zap. Hist. T. 71 z. 2/3 s. 196-197.

2007

332. Augustin Karol (Carl) Gottfried (1685-1761), sekr., lawnik staromiejski, rajca tor. // In: Tor. słow. biogr. T. 5. Toruń. - s. 18-19.

333. Biskup Andrzej Stanisław Załuski w roli pedagoga-moralisty, czyli „młode dziewczęta nigdy samopas wałęsać się nie powinny" (dwa listy do rady Chełmna i chełmińskich benedyktynek z 1741 roku) // In: Literatura - Historia - Dziedzictwo. Prace ofiarowane Profesor Teresie Kostkiewiczowej / red. Tomasz Chachulski, Anna Grześkowiak-Krwawicz. Warszawa: Wyd. Instytutu Badań Literackich PAN. - s. 423-429.

334. Grambau Jerzy (Georg) (1704-1761), kupiec zbożowy, armator, tor. ławnik przedmiejski. // In: Tor. słow. biogr. T. 5. Toruń. - s. 47-48.

335. Jaster Szymon (1713-1772), kupiec i rajca tor., katolik. // In: Tor. słow. biogr. T. 5. Toruń. - s. 65.

336. Koszty żeglugi na Wiśle między Toruniem a Gdańskiem w 1766 roku. Rachunki toruńskiego sternika Franciszka Majewskiego. Kwart. Hist. Kult. Mat. R. 55 nr 1 s. 51-66. 
337. Lustracja województw Prus Królewskich 1765. T. 2: Województwo chełmińskie. Cz. 1: Ziemia michałowska. - Toruń: Tow. Nauk. w Toruniu; Uniw. M. Kopernika w Toruniu; Instytut Historii PAN. - XIX s., 154 s., [1] s.

338. Najstarszy spis mieszkańców Brodnicy z 1662 roku // In: Szkice brodnickie T. 3 / red. Kazimierz Grążawski. - Brodnica: Wyd. MULTI; Tow. Miłośników Ziemi Michałowskiej. - s. 161-171.

339. Podstawowe problemy skarbowe i ekonomiczne Rzeczypospolitej przełomu czasów saskich i stanisławowskich w ocenie sasko-polskiego konsyliarza Jana Beniamina Steinhausera // In: Między Zachodem a Wschodem. T. 4: Życie gospodarcze Rzeczypospolitej w XVI-XVIII wieku / red. Jacek Wijaczka. - Toruń: Wyd. Adam Marszałek. - s. 144-163.

340. Stoliński (Kalkstein-Stoliński) Melchior h. Trzy Pasy (Kos) (ok. 1691-1762), chorąży chełmiński, podkomorzy chełmiński, poseł na sejmy. // In: Pol. słow. biogr. T. 44. Warszawa. - s. 73-75.

341. Urażone magnackie ambicje czy racja stanu? U źródeł opozycji wobec kandydatury Stanisława Leszczyńskiego w bezkrólewiu 1733 roku. // In: Spory o państwo w dobie nowożytnej. Między racją stanu a partykularyzmem / red. Zbigniew Anusik. - Łódź: Wyd. Uniw. Łódzkiego. - s. 187-199.

342. Vollmer Gottfried Dietrich Leberecht (1770-1815), tor. wyd., niem. ,jakobin“, publicysta, drukarz i księgarz. // In: Tor. słow. biogr. T. 5. Toruń. - s. 228-229.

343. Waschlager Jan Michał (Johann Michael) (1741-1801), ławnik staromiejski, rysownik i sztycharz tor. // In: Tor. słow. biogr. T. 5. Torun. - s. 229-230.

344. Waschlager Jerzy (Georg) Daniel (1702-1757), sekr. Rady, rezydent na dworze król., rajca tor. // In: Tor. słow. biogr. T. 5. Toruń. - s. 230-231.

345. Waschlager Karol (Carl) Jakub (1718-1797), rajca i burmistrz tor. // In: Tor. słow. biogr. T. 5. Toruń. - s. 231-232.

346. Zernecke Jan (Johann) Samuel (1713-1780), sekr. rady, rajca i burmistrz tor. // In: Tor. słow. biogr. T. 5. Toruń. - s. 246-247.

347. Rec. - Bąkowski-Kois Dariusz: Zarządcy dóbr Elżbiety Sieniawskiej. Studium z historii mentalności. Kraków, 2005. - Wiek Oświec. T. 23 s. 281-284.

348. Rec. - Bondyra Wiesław: Reprezentacja sejmowa Rusi Czerwonej w czasach saskich. Lublin, 2005. - Wiek Oświec. T. 23 s. 278-281.

349. Rec. - Niedziela Rafał: Pisma polityczne w okresie bezkrólewia i wojen o tron polski po śmierci Augusta II Mocnego (1733-1736). Kraków, 2005. - Wiek Oświec. T. 23 s. 274-278.

\section{8}

350. Edmund Cieślak (1922-2007). Wiek Oświec. T. 24 s. 281-282.

351. Udział szlachty Prus Królewskich w życiu politycznym prowincji I Rzeczypospolitej w latach 1733-1772 (ujęcie statystyczne) // In: Społeczeństwo staropolskie. Seria nowa. T. 1: Społeczeństwo a polityka / red. Andrzej Karpiński, Iwona Dacka-Górzyńska. - Warszawa: Wyd. DiG. - s. 65-93. 
352. Józef Zając (13 XII 1945 - 23 VIII 2008). Kwart. Hist. R. 116 nr 3 s. 209-212. [Wspólnie z Przemysławem Wojciechowskim]

353. Lustracja województw Prus Królewskich. T. 2: Województwo chełmińskie. Cz. 2: Ziemia Chełmińska. - Toruń: Tow. Naukowe w Toruniu; Uniw. M. Kopernika w Toruniu; Instytut Historii PAN. - 203 s.

354. Rywalizacja dwóch dyplomatów cesarskiego i francuskiego w Polsce 1733 roku Heinrich Wilhelm von Wilczek i Antoine-Felix de Monti // In: Polska wobec wielkich konfliktów w Europie nowożytnej. Z dziejów dyplomacji i stosunków międzynarodowych w XV-XVIII wieku / red. Ryszard Skowron. - Kraków: Societas Vistulana. - s. 495-512.

355. Rec. - Bogucka Maria: Człowiek i świat. Studia z dziejów kultury i mentalności XV-XVIII w. Warszawa, 2008. - Acta Pol. Hist. vol. 99 s. 171-175.

356. Rec. - Bogucka Maria: Człowiek i świat. Studia z dziejów kultury i mentalności XV-XVIII w. Warszawa, 2008. - Kwart. Hist. R. 116 nr 3 s. 161-166.

357. Rec. - Bogucka Maria: Ludzie z Kresów. Warszawa, 2009. - Klio T. 13 s. 211-214.

358. Rec. - Burnett George: Obraz obecnego stanu Polski. Warszawa, 2008. - Wiek Oświec. T. 25 s. $119-128$.

359. Rec. - „Censura reflexionum amici ad amicum ...”: pismo polityczne w obronie króla Stanisława Leszczyńskiego z 1733 roku / oprac. Rafał Niedziela. Kraków, 2007. - Wiek Oświec. T. 25 s. 116-119.

360. Rec. - „Interes WM Pana wspomniałem Królowi Jmc...”. Listy Jana Jerzego Przebendowskiego podskarbiego wielkiego koronnego do Adama Mikołaja Sieniawskiego wojewody bełskiego i hetmana wielkiego koronnego z lat 1704-1725 / wyd. A. Perłakowski. Kraków, 2007. - Kilka uwag na marginesie listów podskarbiego wielkiego koronnego Jana Jerzego Przebendowskiego z początków XVIII wieku. Zap. Hist. T. 74 z. 1 s. 105-114.

361. Rec. - Michalski Jerzy: Studia historyczne z XVIII i XIX wieku. T. 1-2. Warszawa, 2007. - Kwart. Hist. R. 116 nr 3 s. 188-193.

2010

362. Bärholtz Teofil Daniel (1682/3-1731). // In: Tor. słow. biogr. T. 6. Toruń. - s. 17.

363. Epoka saska w ujęciu Jerzego Michalskiego // In: W kręgu badaczy dziejów politycznych XVIII wieku. Józef Feldman, Emanuel Rostworowski, Jerzy Michalski / red. Zofia Zielińska, Wojciech Kriegseisen. - Warszawa: Semper. - s. 67-77.

364. Fenger Jakub (1729-1797), kupiec zbożowy i bankier, rajca tor. // In: Tor. słow. biogr. T. 6. Toruń. - s. 36-37.

365. Fenger Jan (Johann) (ok. 1685-1747), kupiec tor., członek Trzeciego Ordynku. // In: Tor. słow. biogr. T. 6. Toruń. - s. 37-38.

366. Janitzen (Jaenitzen, Jantzen) Daniel Krzysztof (Daniel Christoph) (1650-1711), tor. kupiec, rajca miejski i poczmistrz. // In: Tor. słow. biogr. T. 6. Toruń. - s. 63-64.

367. Maryanski [Mariański] Józef Ignacy (1720-1761), kupiec i rajca tor. // In: Tor. słow. biogr. T. 6. Toruń. - s. 105-106. 
368. Kujawy w bezkrólewiu 1733 roku. Ziem. Kuj. T. 23 s. 37-54.

369. Mieszczanin szlachcicem, a nawet starostą. Kariera konsyliarza Karola Schmidta w osiemnastowiecznej Rzeczypospolitej // In: Człowiek w teatrze świata. Studia o historii i kulturze dedykowane Profesorowi Stanisławowi Grzybowskiemu. - Kraków: Wyd. Nauk. Uniw. Pedagogicznego. - s. 349-359.

370. Nowe pałace dwóch podskarbich wielkich koronnych $\mathrm{z}$ doby saskiej Jana Jerzego Przebendowskiego i Jana Ansgarego Czapskiego jako symbole awansu społecznego // In: Dom, majątek, klient, sługa. Manifestacja pozycji elit w przestrzeni materialnej i społecznej (XIII-XIX wiek) / red. Marcin R. Pauk, Monika Saczyńska. - Warszawa: Instytut Archeologii i Etnologii PAN. - s. 179-200.

371. Rola sejmików Prus Królewskich w systemie administracyjno-skarbowym prowincji po reformach Sejmu Niemego z 1717 roku // In: Szlachta europejska w strukturach lokalnych XVI-XVIII wieku / red. Małgorzata Konopnicka, Jarosław Kuczer, Wojciech Strzyżewski. - Zielona Góra: Oficyna Wyd. Uniw. Zielonogórskiego. - s. 165-190.

372. Schultz Andrzej (Andreas) (przed 1650? -1729), rajca i burmistrz tor. // In: Tor. słow. biogr. T. 6. Toruń. - s. 169-170.

373. Thomas Gerhard (1651-1725), rajca i burmistrz tor. // In: Tor. słow. biogr. T. 6. Toruń. - s. $177-178$.

374. U początków „czarnej legendy” czasów saskich. Czasy Nowoż. T. 23 s. 63-84.

375. Wedemeyer Jan Henryk (Johann Heinrich) (1683-1751), rajca tor. // In: Tor. słow. biogr. T. 6. Toruń. - s. 182-183.

376. Rec. - 1786 metų kelionès ị Vilnių dienoraštis. Żurnal podróży do Wilna z roku 1786 / Ludwika Byszewska. Vilnius, 2008. - Zap. Hist. T. 75 z. 2 s. 181-185.

377. Rec. - Akta sejmikowe województw poznańskiego i kaliskiego: lata 1696-1732 / wyd. Michał Zwierzykowski. Poznań, 2008. - Wiek Oświec. T. 26 s. 126-130.

378. Rec. - Ciesielski Tomasz: Armia koronna w czasach Augusta III. Warszawa, 2009. - Wiek Oświec. T. 26 s. 141-147.

\section{1}

379. Danziger Einkäufe und Ausgaben des Bischofs Adam Stanisław Grabowski Mitte des 18. Jahrhunderts. Stud. Marit. Vol. 24 s. 87-100.

380. Jeszcze o nazwach dwóch części Prus w XVIII wieku. Czasy Nowoż. T. 24 s. 91-104.

381. Lustracja województw Prus Królewskich 1765. T. 3: Województwo malborskie. - Toruń: Tow. Nauk. w Toruniu; Uniw. M. Kopernika w Toruniu; Instytut Historii PAN - 134 s.

382. Postawa polityczna Załuskich w dobie bezkrólewia i podwójnej elekcji z lat 1733-1736 // In: Bracia Załuscy - ich epoka i dzieło. Zbiór studiów / red. Dorota Dukwicz. - Warszawa: Biblioteka Narodowa. - s. 11-27.

383. Z życia towarzyskiego polskich elit szlachecko-magnackich w Gdańsku w połowie 1757 roku (Przebendowscy, Adam Kazimierz Czartoryski i wielu innych). // In: Przyjemność w kulturze epoki rozumu / red. Teresa Kostkiewiczowa. - Warszawa: Wyd. DiG. - s. 207-219.

384. Rec. - Aufklärung und Kulturtransfer in Mittel- und Osteuropa. Hannover, 2009. - Czasy Nowoż. T. 24 s. 297-300. 
385. Rec. - Kosińska Urszula: Sondaż czy prowokacja? Sprawa Lehmanna z 1721 roku, czyli o rzekomych planach rozbiorowych Augusta II. Warszawa, 2009. - Wiek Oświec. T. 27 s. $300-302$.

386. Rec. - Polnisch-österreichische Kontakte sowie Militärbündnisse 1618-1918: Symposium und Abendvortrag 11. und 12. September 2008: Acta. Wien, 2009. - Czasy Nowoż. T. 24 s. 281-286.

\section{2}

387. Dzieje polityczne Prus Królewskich do rozbiorów Rzeczypospolitej (1772-1793) // In: Prusy Królewskie 1454-1772. Społeczeństwo - Kultura - Gospodarka / red. Edmund Kizik. - Gdańsk: Muzeum Narodowe w Gdańsku. - s. 72-94.

388. Konsyliarz Jan Beniamin Steinhauser o swoich kwerendach archiwalnych i o stanie Archiwum Koronnego w 1765 roku // In: Silva rerum, opera historica, diplomatica et archivistica continens, Andreae Tomczak dedicata / red. Waldemar Chorążyczewski, Marcin Hlebionek. - Toruń-Warszawa: Stow. Archiwistów Polskich. - s. 73-93.

389. Koszty podróży i pobytu w Warszawie toruńskich deputowanych na sejm 1767 roku. Kwart. Hist. Kult. Mat. R. 60 nr 3 s. 443-456.

390. Listy Rady Torunia w XVIII wieku: adresaci, częstotliwość, zasięg terytorialny. Klio T. $23 \mathrm{nr} 4$ s. 129-142.

391. Profesor Marian Biskup: (19 XII 1922 - 16 IV 2012). Klio T. 20 nr 1 s. 315-318.

392. Radziwiłłowskie kłopoty ze spławem do Gdańska i Królewca w 1733 roku. Zap. Hist. T. 77 z. 3 s. $7-21$.

393. Z doświadczeń edytora osiemnastowiecznych lustracji i inwentarzy - czy instrukcja wydawnicza jest w ogóle potrzebna? // In: Teoria i praktyka edycji nowożytnych źródeł w Polsce (XVI-XVIII w.) / red. Adam Perłakowski. - Kraków: Tow. Wyd. „Historia Iagellonica". - s. 143-158.

394. Rec. - Kuras Katarzyna: Współpracownicy i klienci Augusta Czartoryskiego w czasach saskich. Kraków, 2010. - Czasy Nowoż. T. 25 s. 243-247.

395. Rec. - Syta Krzysztof: Archiwa magnackie w XVIII wieku. Studium kultury kancelaryjno-archiwalnej. Toruń, 2010. - Wiek Oświec. T. 28 s. 191-198.

\section{3}

396. August III Sas i Stanisław August Poniatowski. Obrazy sarmaty i Europejczyka. // In: Europejski wiek osiemnasty. Uniwersalizm myśli, różnorodność dróg / red. Marek Dębowski, Anna Grześkowiak-Krwawicz, Michał Zwierzykowski. - Kraków: Societas Vistulana. - s. 71-79.

397. Codzienne kłopoty, wielkie interesy i podwójna elekcja. Korespondencja radziwiłłowskich urzędników z księżną Anną z Sanguszków Radziwiłłową i jej synem Michałem Kazimierzem z 1733/1734 roku. - Warszawa: Wyd. DiG. - XXXII s., 226 s.

398. Podróże litewskiego magnata do Gdańska, Człuchowa, a nawet i dalej... Fragmenty „Diariusza” Michała Kazimierza Radziwiłła „Rybeńki” z lat 1751, 1737 i 1752. - Warszawa: Instytut Historii PAN. - 146 s. 
399. Dzieje fryderycjańskich Prus w XVIII wieku, czyli o wyższości absolutyzmu nad szlachecką wolnością. Kwart. Hist. R. $120 \mathrm{nr} 3$ s. 575-593.

400. Siedziby szlachty chełmińskiej w XVIII wieku // In: Zamki, pałace, dwory i ich mieszkańcy w regionie kujawsko-pomorskim / red. Waldemar Rozynkowski, Małgorzata Strzelecka, Michał Targowski. - Toruń: Wyd. Nauk. Uniw. M. Kopernika w Toruniu. - s. 33-62.

401. Szembek Aleksander Kazimierz h. własnego (zm. 1756), poseł na sejmy, stolnik koronny, wojewoda sieradzki. // In: Pol. słow. biogr. T. 48. Warszawa. - s. 27-29.

402. Szembek Franciszek Jakub h. własnego (ok. 1700-1765), poseł na sejmy, chorąży koronny, wojewoda inflancki, bibliofil. // In: Pol. słow. biogr. T. 48. Warszawa. - s. 52-54 .

403. Rec. - Kościelak Sławomir: Katolicy w protestanckim Gdańsku od drugiej połowy XVI do końca XVIII wieku. Gdańsk, 2012. - Zap. Hist. T. 78, z. 4 s. 163-169.

404. Rec. - Wadas Jolanta: Stanisław Hoszowski - uczony i nauczyciel. Kraków, 2012. Zap. Hist. T. 78 z. 4 s. 174-178.

405. Rec. - Wyszomirska Monika, Perłakowski Adam: Opisanie krótkie niektórych interesów wewnętrznych Najjaśniejszej Rzeczypospolitej Polskiej w roku 1762 traktowanych, $\mathrm{z}$ francuzkiego języka na polski przełożone za pozwoleniem zwierzchności w drukarni miclerowskiej wydane r. p. 1764 oraz Mowa JW JM Księdza Józefa Andrzeja Załuskiego biskupa kijowskiego i czerniechowskiego miana podczas Senatus Consilium warszawskiego die 25 Novembris 1762. Kraków, 2011. - Wiek Oświec. T. 29 s. $279-282$.

\section{4}

406. Bydgoski epizod w życiu Stanisława Leszczyńskiego - wokół ucieczki króla do Gdańska we wrześniu 1733 roku. Zap. Hist. T. 79 z. 2 s. 73-95.

407. Gra pozorów: zabiegi dyplomacji cesarskiej o rosyjską interwencję zbrojną w Rzeczypospolitej w 1733 r. // In: W cieniu wojen i rozbiorów. Studia z dziejów Rzeczypospolitej XVIII i początków XIX wieku / red. Urszula Kosińska, Dorota Dukwicz, Adam Danilczyk. - Warszawa: Neriton. - s. 137-160.

408. Podróż królewny Sobieskiej a także kilka magnackich Grand Tour z XVII/XVIII wieku w relacjach Samuela Kazimierza Szwykowskiego. Czasy Nowoż. T. 27 s. 31-58. [Wspólnie z Adamem Kucharskim]

409. Wizerunek barokowego sarmaty i oświeceniowego Europejczyka, czyli August III Wettyn i Stanisław August Poniatowski. Wieki Stare i Nowe T. 6 s. 38-57.

410. Rec. - Filipczak Witold: Życie sejmikowe prowincji wielkopolskiej w latach 1780-1786. Łódź, 2012. - Czasy Nowoż. T. 27 s. 315-320.

411. Rec. - Perłakowski Adam: Kariera i upadek królewskiego faworyta: Aleksander Józef Sułkowski w latach 1695-1738, Kraków 2013. - Zmienne losy faworyta Wettynów. Wiek Oświec. T. 30 s. 211-219.

412. Rec. - Testamenty szlachty Prus Królewskich z XVII wieku. Warszawa, 2013. - Zap. Hist. T. 79 z. 1 s. 137-140. 